\title{
Promoting a reading culture in school community: how to engage reading activities cross curricula, directors, teachers, students, parents, administrative services, local authorities, public libraries and other partners - Relating a project
}

\author{
Ana Bela Martins \\ School Librarian Advisor \\ School Libraries Network Office - Ministry of Education \\ Portugal
}

Alexandra Marques

National Reading Plan - Ministry of Education

Portugal

\begin{abstract}
The main purpose of this paper is to present how an intensive collaboration between the National Portuguese Reading Plan and the School Libraries Network Programme plays an important role in the promotion of reading literacy as a baseline to develop all kinds of other literacy abilities and empower the role of school libraries and the collaborative work between the school community and the school library, by reporting on one of the most significant projects, which shows the relevance of this partnership. School libraries are a privileged structure in the school for skill development, not only in accessing information, available locally or remotely, enabling students with critical thinking, transforming information to knowledge, supporting curricula, but also in readers training and the promotion of reading habits, which is a basic tool for lifelong learning.
\end{abstract}

\section{Introduction}

School Libraries Network Programme, launched in 1996, has as a main goal, to install and develop libraries in state schools at every level, supplying its users with the necessary resources to read, access, use and produce information, regardless of the format. The organisation and operation of the school libraries are guided by principles, namely its development within a school community perspective, calling for articulation and networking principles such as the collection that should be updated and adjusted to the students and teachers' needs. This includes curricula supporting documents, literature collections, children and young readers and the practice of library interloan.

The integration of schools in the School Libraries Network Programme is made through annual applications. The schools offering the most qualified projects are selected and schools receive technical and financial support for the acquisition of specified equipment and furniture, collections and management software.

Regarding primary schools, the municipality is involved in the installation of school libraries. They have a financial responsibility, when space intervention is necessary. The Public Library is, from the beginning, involved at a technical level, assuring the treatment of all documents and helping schools with the different tasks, namely with the collection procedures. The School Libraries Supporting Service, created to give continuity to this collaborative work, extends its service beyond the technical work to include activities of reading promotion.

These procedures are formalised with the signature of a Cooperation Agreement between the Ministry of Education, the Municipality and the school communities involved. These agreements also include interloan services, allowing a real articulation and sharing of resources which is a significant added value, reinforced by The National Reading Plan.

(C) 2010 IASL, SLAQ and therein by the authors. Diversity Challenge Resilience: School Libraries in Action Proceedings of the $12^{\text {th }}$ Biennial School Library Association of Queensland, the $39^{\text {th }}$ International Association of School Librarianship Annual Conference incorporating the $14^{\text {th }}$ International Forum on Research in School Librarianship, Brisbane QLD Australia, 27 September - 1 October 


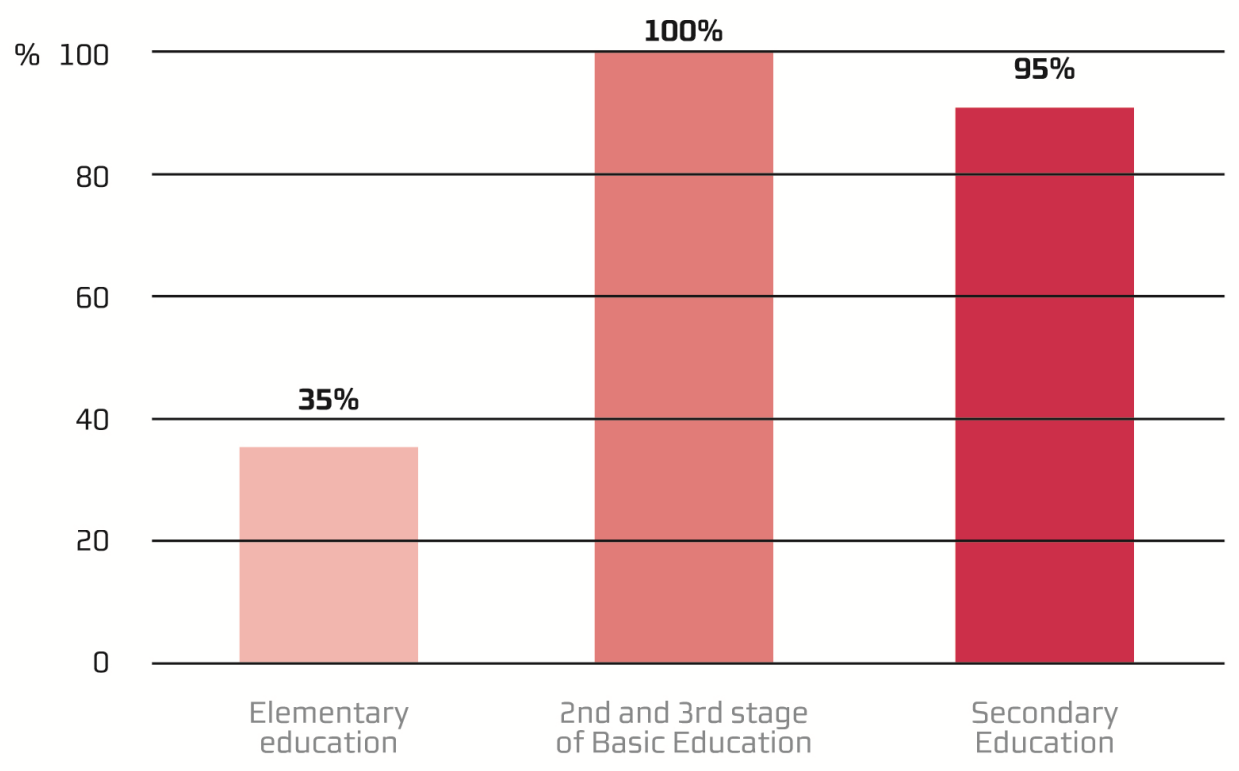

To accomplish its mains goals, School Libraries Network Programme tried to respond to training needs of the teacher-librarian and of the team, either by the continuous teacher training or by higher education institutions. The human resources allocated to school libraries have been consolidated, evidenced by the 2009 law that created the position of the teacher-librarian in all schools with adequate training. As a teacherlibrarian he/she plays an important role, not only in library management, and supporting curricula, but also in pedagogical and cultural promotion. This is evidenced by the articulation with school communities of reading programmes and supporting the activities of the National Reading Plan. The role of teacher-librarian can make the difference. Placing literacies development in the centre of the Educative Project (School Mission Goals) is the first step. The commitment of stakeholders, such as the School Board and all staff, is crucial to accomplish the work strategies to develop collaborative partnership with teachers, support curriculum activities, make connections, create opportunities for cooperative learning and develop a learning environment. Working with a teacher or a group of teachers to provide strategies, materials and resources, according to their needs and evaluating the impact on students' achievement, is the only way to promote changes in the teaching and learning process and place the school library at the core of educational process and as an enhancer of curricular goals.

The School Libraries Network Programme has a vast group of teachers with library training and experience in the management of the school libraries. These teachers are municipal coordinators who provide consultancy and technical support in the field, both in library installation and, later on, in order to optimise the operation and qualified work developed by the team. These teachers are also in charge of encouraging municipal working groups, in collaboration with the public library, in order to develop structured projects in the promotion of reading and literacy. This creates an awareness of the need to adopt resources sharing policies and joint organisation of activities to stimulate the creation of network information management systems. This group of teachers is another important support not only for school libraries but also to the development of national reading plan activities.

Our reading habits and literacy levels are, due to our recent history, (the compulsory education of nine years has only 23 years) lower than in the most of European Community Countries, not only for adult population, but also for young people. Nowadays we know that the development of reading abilities in the early childhood education is important to succeed, not only during the period of formal education, but also in all other aspects and periods of life.

(C) 2010 IASL, SLAQ and therein by the authors. Diversity Challenge Resilience: School Libraries in Action Proceedings of the $12^{\text {th }}$ Biennial School Library Association of Queensland, the $39^{\text {th }}$ International Association of School Librarianship Annual Conference incorporating the $14^{\text {th }}$ International Forum on Research in School Librarianship, Brisbane QLD Australia, 27 September - 1 October 2010 . 
Several sociological studies on reading habits state that school pupils and students no longer read for leisure, or even to satisfy individual curiosities. They are occupied with obligatory school readings. The reading of literature and fiction in general tends to be a way, not only to help developing a personal and social identity, but also to create more profound and grounded literacy capacities, namely the information literacy abilities that are so needed to go through life in today's world. We all know that reading (and hearing) of tales since birth is fundamental to help children grow. Many authors think that their power to change our perceptions, our feelings, even our lives and consequently promote knowledge is unique (Gaarder, 2002).

These beliefs and the need to fight against our literacy levels, lead us to launch the National Reading Plan in 2006. An initiative from the government which is the responsibility of the Ministry of Education together with the Ministry of Culture and the Minister of Parliamentary Affairs Office. The impact of The National Reading Plan is considered a national goal, because we believe that its impact will be much more significant. As the existing research on the Portuguese reality is only partial, the National Reading Plan includes a set of studies which will allow for a better understanding of the reality, and allow for the monitoring and evaluation of the intervention. Research will also be aimed at creating tools which may serve as a guide, to support and motivate reading promoters - teachers, educators, librarians, school librarians, mediators, parents and guardians.

An action plan was conceived, which involved several institutions, schools, public libraries, social institutions, private institutions, civil associations with relevant significance to the educational system. Many were involved in the network between School Libraries and the National Reading Plan.

\section{Coordination of NRP}

- Coordination of the National Reading Plan - an agency based at the Ministry of Education

- Strategic partner responsible for programmes in the Education area - School Library Network Office (RBE)

- Strategic partner responsible for programmes in the Culture area - Directorate-General for Books and Libraries (DGLB)

- Strategic partner responsible for initiatives in the media - Institute for the Media (ICS)

- General Coordination of Studies including Assessment of the Plan - Educational System Statistics and Assessment Office - (GEPE - Ministry of Education)

The National Reading Plan launched measures that cover the various sectors of the population from infancy to adulthood. However, studies show that basic skills are either acquired at an early age, in the first stages of life, or else give rise to difficulties that progressively accumulate, multiply and transform into almost insurmountable obstacles.

This premise makes it advisable that, in the first phase, children in pre-school education and the first six years of basic education should be chosen as the priority target audience. In order for children and young people to be reached, people mainly responsible for their education must be mobilised. For this reason, childcare workers and teachers, parents and caregivers, librarians, literacy mediators and reading animators are also considered to be a highly important target audience. On other hand we thought, from the beginning, that school libraries must have an important role supporting the National Reading Plan in schools of all levels. This is aligned to its important role and experience in readers training and in the promotion of reading habits. This importance is confirmed by the School Libraries Network Office being an institutional coordinator member of National Reading Plan.

- National Reading Plan has programmes to encourage and promote reading:

$\circ$ in school contexts

- classrooms

- school libraries

$\circ$ in the context of public libraries and other community spaces

0 in the family/leisure time context

(C) 2010 IASL, SLAQ and therein by the authors. Diversity Challenge Resilience: School Libraries in Action Proceedings of the $12^{\text {th }}$ Biennial School Library Association of Queensland, the $39^{\text {th }}$ International Association of School Librarianship Annual Conference incorporating the $14^{\text {th }}$ International Forum on Research in School Librarianship, Brisbane QLD Australia, 27 September - 1 October 
$\bigcirc$ in unconventional reading contexts

- Experimental projects for the promotion of reading

It is one of these experimental projects for the promotion of reading we want to relate in this paper that shows the partnership between School Libraries Network Programme and National Reading Plan. The project aLeR + (reading more and more) is an initiative of the National Reading Plan and the School Libraries Network Programme, designed on the basis of Reading Connects project from the National Trust Reading, UK. Reading Connects project incorporates a network of schools in the UK and has a significant impact on raising levels of literacy and the consolidation of the reading habits of the school population.

The National Reading Plan and the School Libraries Network Programme launched this project in 2008/09 on a trial basis in 33 schools of different levels of education. The main goal of this project, supported by the two national programmes through financial and technical support, is the creation of a culture of school where the pleasure of reading and reading are central elements cross all curricula and extracurricular activities. All stakeholders of the educational community: students, teachers, staff, teacher-librarians and librarians, families, volunteers, local authorities, citizens and the civil society organisations, promote a network of schools where the development of a reading culture is a priority. This network allows members to share best practice, as well as disseminating information. We offer some resources like a set of guidelines

(Presentation, Guidelines for the implementation of the project, Guidelines for family involvement), links in the website of SLNP and NRP to others reading projects around the world, and a Moodle platform to interact with schools. To accomplish these goals, a team led by a member of School Libraries Network Office and by a member of National Reading provides technical and financial support to all schools involved in the project according to the project presented by each school.

To encourage schools to set reading and the pleasure of reading in the centre of their educational project and its activities, schools must follow a set of guidelines:

- To set the pleasure of reading in the centre of its efforts to raise the standards of learning for students and educational success;

- To involve all the elements of the educational community in reading promotion - educators, teachers, staff, parents and librarians, local authorities, etc

- To work in partnership with families to encourage reading at home...

aLeR+ has six main domains (strategy to all school, reading promotion, celebrating festivals and groups of interest, school library, school community involvement, family involvement,). Schools choose the areas they want to work in and develop a reading culture in the school community.

At the moment, we only have perceptive findings reported by the first 33 schools involved in the project that shows this year a real progress in different reading areas. First, reading promotion related to literature was the main focus in primary schools and the involvement of families. In the second year, $90 \%$ of the project work was with curricula in all the schools and also with a strong impact in school community, through public libraries and other civil organisations.

Last year more than 30 schools integrated this project. Last July, at the second annual meeting, more than 14 schools were invited to join the project. Due to the different dimensions of the project we decided to grow slowly, in a sustainable way, by choosing schools already with practices in reading promotion and in a position to influence school policies.

We report the experiences of these schools in the development of an integrated culture of reading within the whole school and educational community through

- our findings on a preliminary basis,

- close supervision of the lead team of all schools involved,

- presentation of activities at the annual meeting of the project, and

(C) 2010 IASL, SLAQ and therein by the authors. Diversity Challenge Resilience: School Libraries in Action Proceedings of the $12^{\text {th }}$ Biennial School Library Association of Queensland, the $39^{\text {th }}$ International Association of School Librarianship Annual Conference incorporating the $14^{\text {th }}$ International Forum on Research in School Librarianship, Brisbane QLD Australia, 27 September - 1 October 2010 . 
- the report of external evaluation of School Libraries Network Programme and National Reading Plan, made by a prestigious university.

The two programs to achieve reading habits goals: SLNP and NRP:

- a major sensibility to reading issues,

- reading as a cross curricula activity,

- a major engagement of teachers of different subjects

- reading is a daily routine either in formal or informal schooling activities,

- more coherent and consistent reading promotion activities,

- a greater interaction between school library and teachers,

- a greater interaction between public library, school library and school community,

- parents and local community, including local authorities are much more involved.

In same schools, the teacher-librarian and teachers of different subjects report an increasing impact on students achievements, but we do not have data yet to confirm their perceptions.

We believe that in sharing our experience we will benefit from other contributions in the field.

\section{References}

Gaarder, J. (2002). Books for a world without readers. Basil: $28^{\text {th }}$ Conference of the IBBY. 